\title{
Analysis on The Roles of Stakeholders in The Management of Integrated Breeding Beef Cattle Farm Program at PT KPC East Kutai
}

\author{
J. Ariansyaha ${ }^{\mathrm{a}, *}$, A. Ismail ${ }^{\mathrm{b}, \#,}, \&$ L. Abdullah ${ }^{\mathrm{c}, \#}$ \\ ${ }^{a}$ Agriculture Academy of East Kutai \\ Jln. Soekarno Hatta No. 1 Sangatta Utara, East Kutai, East Kalimantan, Indonesia \\ ${ }^{b}$ Department of Resource and Environment Economy, Faculty of Economics and Management, \\ Bogor Agricultural University \\ 'Department of Nutrition and Feed Technology, Faculty of Animal Science, \\ Bogor Agricultural University \\ Kampus IPB Darmaga, Bogor, 16680, West Java, Indonesia \\ (Received 13-06-2013; Reviewed 22-07-2013; Accepted 01-10-2013)
}

\begin{abstract}
An analysis of the roles of stakeholders was conducted as a continuity program of Peternakan Sapi Terpadu (PESAT; integrated beef cattle farm) following the coal mining deactivation by PT Kaltim Prima Coal (KPC) of East Kutai, East Kalimantan. The purpose of this study was to formulate stakeholders relation in the future program. The stakeholders involved in this program were PT KPC, local breeders, Sekolah Tinggi Ilmu Pertanian (STIPER; Agriculture Academy) of East Kutai, and the local government of East Kutai. The stakeholders analysis was based on the variables of the importance and influence from every analyzed stakeholder. The analysis model used here was the model introduced by Reed et al. (2009). According to the result of the stakeholders analysis, PT KPC was in the key-player quadrant, which score is 25 in both of the interest and the influencial level, while the three others, such as, local breeders, STIPER of East Kutai, and the East Kutai Government were in the subject quadrant. Their score were 24 and 7 for Local breeders, 21 and 9 for STIPER of East Kutai, and 16 and 13 for The East Kutai Government. It means, they had high interest but low influence to the program. The conclusion of this analysis shows that PT KPC is still dominating in the PESAT program management, whereas the three other stakeholders are acting merely as program users that have low involvement in the program management.
\end{abstract}

Key words: analysis, East Kutai, PESAT, PT KPC, stakeholder

\section{ABSTRAK}

Analisis hubungan stakeholder dilakukan dalam rangka keberlanjutan program peternakan sapi terpadu (PESAT) pasca ditutupnya kegiatan pertambangan oleh PT KPC Kutai Timur. Penelitian ini bertujuan untuk merumuskan hubungan para stakeholder dalam pengelolaan program PESAT di masa yang akan datang. Stakeholder yang terlibat dalam program ini diantaranya PT KPC, peternak lokal, Kampus STIPER Kutai Timur, dan PEMDA Kutai Timur. Analisis stakeholder dilakukan berdasarkan variabel kepentingan dan pengaruh dari setiap stakeholder yang dianalisis. Model analisis yang digunakan adalah model yang diperkenalkan oleh Reed et al. (2009). Berdasarkan analisis stakeholder tersebut, didapatkan hasil yang memperlihatkan bahwa PT KPC berada di kuadran key player dengan skor tingkat kepentingan dan pengaruh sebesar 25, yaitu stakeholder yang memiliki tingkat kepentingan dan pengaruh yang tinggi terhadap program, sedangkan ketiga stakeholder lainnya, seperti peternak lokal, Kampus STIPER Kutai Timur, dan PEMDA Kutai Timur berada di kuadran subject, yaitu stakeholder yang memiliki tingkat kepentingan tinggi tetapi pengaruhnya rendah terhadap program. Masing-masing stakeholder tersebut memiliki skor tingkat kepentingan dan pengaruh yang berbeda, secara berurutan sebesar 24 dan 7, 21 dan 9, serta 16 dan 13 . Kesimpulan dari analisis ini adalah bahwa PT KPC masih mendominasi dalam pengelolaan program PESAT, sedangkan ketiga stakeholder lainnya baru sebatas pengguna program yang memiliki keterlibatan rendah dalam pengelolaan program.

Kata kunci: analisis, Kutai Timur, PESAT, PT KPC, stakeholder

*Corresponding author:

E-mail: joni_hublu@yahoo.com 


\section{INTRODUCTION}

Integrated breeding beef cattle farm program (in Indonesian: Peternakan Sapi Terpadu aka PESAT) run by PT KPC of East Kutai is one of the Company Social Responsibility (CSR) programs that optimizes the available used mining areas. In those areas, there is a breeding activity for Balinese beef cattle integrated with other activities, such as beef cattle farm training for the local breeders, beef cattle breeding, crop cultivation, cattle wastes recycling, and educative activities. Balinese cattle selected based on the consideration that it is a kind of local cattle in East Kutai. Gunawan \& Jakaria (2011) said that the Bali cattle is one of the few native Indonesian cattle which plays a major role in the production of meat. Since its establishment in the end of 2009, a meaningful progress has started to rise on those stakeholders thanks to the PESAT programs. There are four benefited stakeholders; PT KPC as the program owner and manager, the local breeders as the group that receives the training and internship program in beef cattle farming, STIPER of East Kutai for being able to use the farm and the entire facilities provided by the company (PT KPC) to support the students field practices, and the local government of East Kutai for being assisted by the program to increase the number of cattle population in order to promote the national meat self-supply. Since the PESAT program is a CSR program whose objective designed to meet the need of people, thus it takes every stakeholder involvement to keep the program well-executed. In the process, the PESAT management evaluated this program unsatisfactory. The three stages of the training program showed a relatively low percentage of successful breeders, therefore, it is crucial to make the roles of the stakeholders analysis in their relation on the PESAT program, so the program will be sustainable in the future.

Stakeholder analysis became widely used by regulators, government, Non-Governmental Organization (NGO), business purposes, and media of various scopes (Friedman \& Miles, 2006). Stakeholder analysis approach has been adapted enormously; once it was usually used for business management only, now it has its own part in policy, development, and management of natural resources (Reed et al., 2009). Today's literature advancement in natural resources management and involvement of stakeholders are growing even some more (Fraser et al., 2006; Stringer et al., 2006).

In a profound research done by Iqbal (2007), it suggests that the roles of stakeholders who are affected-whether positively (they get benefited) or negatively (un-voluntarily)-by a certain program or activity, relatively less involved in an actual situation. That is why an understanding of the existence of stakeholders is absolutely needed; it cannot be a stakeholders concern only. This analysis is conducted for the sake of identifying the importance and influence of the stakeholders on the running program agenda. Stakeholder analysis is a really vital instrument in getting information of anyone who is possibly affected by a program and anyone who is also possibly affecting a program (Rietbergen \& Narayan, 1998). The purpose of this study was to formulate stakeholders relation in the future program.

\section{METHODS}

This research took a month in February 2013 to be exact. The research object was a PESAT (Peternakan Sapi Terpadu; integrated breeding beef cattle farm) program of PT KPC East Kutai. It applied quantitative and qualitative as research methods. Quantitative data in the form of scores or values of each variable are defined and subsequently accumulated to determine the position of each stakeholder. The data obtained was analyzed based on the stakeholder analysis by Reed et al. (2009) and descriptive analysis. Purposive sampling technique was used to determine respondents for this research. The respondents are the stakeholders who related -on PESAT program directly, influences and / or is influenced by the development of policy, programs, and activities. They are four people who had an important position and representative of four surveyed stakeholders, those are from PT KPC East Kutai, the local government of East Kutai, Sekolah Tinggi Ilmu Pertanian (STIPER; Agriculture Academy) of East Kutai, and the local breeders joining the PESAT program.

The data was collected through questionnaire-using interviews, field observations, and document studies. The material of questionnaires consisted of the roles, the benefits received, the interests that may be the opposite, the expectations, and the assessment of the program based on the level of stakeholders importance and influence. The amount of importance assessed by 5 variables, namely the involvement of the stakeholders in succeeding the PESAT program, the compatibility between the stakeholders work objectives/programs with the PESAT program, the contribution of each stakeholder related to the program, the advantages gained by the stakeholders out of the PESAT program, and the importance of the stakeholders in the continued program. As with the importance, the amount of the influence assessed by 5 variables, namely the role of the power to the PESAT program, the level/degree of the foundations in decision making, financial support, human resources support and relations with the other stakeholders.

The steps in running the stakeholder analysis (Reed et al., 2009) are mentioned as follows: (1) identify the stakeholders and the roles they hold, (2) differentiate and categorize the stakeholders according to their importance and influence, and (3) define the relationships among the stakeholders. In the second step, all of the stakeholders identified were mapped into a matrix of stakeholder analysis based on how much their importance and influences are. Using a Likert scale, each of those two variables would get a maximum score of 25 points. After every stakeholder scores in the importance variable and influence variable were calculated, next the scores were illustrated in a matrix of importance and influence as shown in the Figure 1.

\section{RESULTS AND DISCUSSION}

Stakeholder analysis is performed to identify interests, importance, and influence of stakeholders on a running specified program. In this research, the goal is to know and understand the positions of each stakeholder 


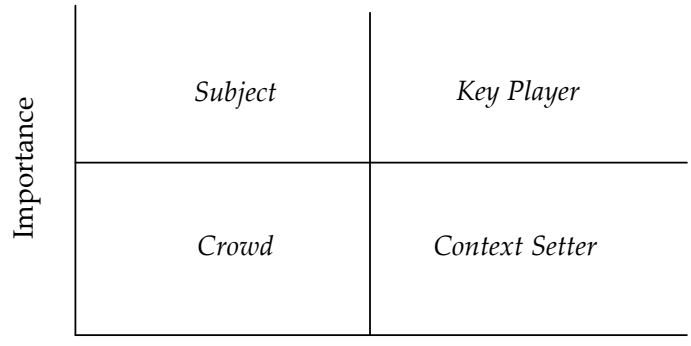

Influence

Figure 1. Matrix of importance-influence (Reed et al., 2009)

based on their importance and influence. Stakeholder identifications are commonly conducted repeatedly and as it goes, a follow-up analysis might be added. For instance, the follow-up analysis could be experts opinions, interviews, snowball sampling, or even a total combination of them all (Reed et al., 2009). Stakeholders involved in an analysis are stakeholders who actually are being in a certain situation (Ackermann \& Eden, 2011). PESAT program operated by PT KPC East Kutai is currently relating to some authorized parties. These parties are the company itself (PT KPC), the local government of East Kutai in which this case is the Regional Farm Board, STIPER of East Kutai, and the local breeders.

In business management, the on-going realization is stakeholders are capable of influencing the success of the led company naturally (Brugha \& Zsuzsa, 2000). Every stakeholder has its own part regarding the PESAT program. PT KPC as a directly responsible party for the program plays significant roles, like preparing the ready-to-use areas, providing the building complete with the necessary facilities, and also getting the tools and organizations needed for the program operation set up. The other PT KPC tasks are to run the PESAT program management, coordinate the internship program, completely fund the program, develop partnerships for product consumption and marketing, plus do monitoring and evaluation.

The local government of East Kutai is on board too in succeeding the PESAT program. They are in charge for permitting people to use the areas, providing the training instructors, educating the breeder groups about the program, and giving suggestions concerning the Balinese cattle expense also the cures for ill cattle. The local government of East Kutai hopes this program can really benefit for the people, especially in the transfer of knowledge in the field of dairy farms. In addition, the local government of East Kutai hope the training is done not only especially for breeders, but also for the people whose jobs are not breeders, for example, employees of PT KPC itself as an alternative preparation work after mine closed in 2021. The local government of East Kutai recognizes that the existence of this program will greatly assist in the genetic improvement of local cattle in East Kutai, in addition to helpful also in the addition of the cattle population in the area.

What STIPER of East Kutai contributes for this program are providing training instructors and us- ing PESAT as a field laboratory, also as a research and Praktik Kerja Lapangan (PKL; General Field Study) ground. The local breeders are too as crucial as the three others. The success of the program depends on them; as fully joining the training course from the very beginning to the end and joining the activity of cattle breeding in a cattle shed during the internship do count. Hopes that emerged from STIPER no less magnitude. This campus is aware of the magnitude of the benefits obtained on the program, namely that there is a cattle shed can be used as a field laboratory for the campus, especially existing written agreement between PT KPC with STIPER about it. STIPER expect more easy access to the use of the cage and one day after mine closure cattle shed there can be donated to the college, so that the utilization can be optimized.

After identifying each stakeholder parts, then the next step is to distinguish and categorize the stakeholders according to their importance and influence. The stakeholders were mapped into a matrix called the matrix of stakeholder analysis. This method that applied the importance and influence categories is quite well-known nowadays. Based on both elements, the stakeholders were classified into clusters of key player, context setters, subject, and crowd (De Lopez, 2001; Reed et al., 2009). The strength of the importance of the stakeholders in the PESAT program analysis was evaluated from their involvement in succeeding the program, the compatibility between the stakeholders work objectives with the program, the contribution of each stakeholder related to the program, the advantages gained by the stakeholders out of the program, and their importance in the continued PESAT program. The strength of the stakeholders influences were scored based on the role of their power over the PESAT program, the degree / level of the foundations in decisions making, the financial support, the human resources support, and the relations with other stakeholders.

The stakeholders who possess a high level of importance are PT KPC, the breeders, and STIPER of East Kutai (Table 1). Each stakeholder has a level score of influence of 25, 24, and 21 points. PT KPC as a company that owns and runs the program feels that this PESAT program is very valuable to them. The benefit of the program is numerous and the most important thing is it lights positive effect on the company relationship with the local society which is the company social commitment to community. Hence, the contribution of the company for the PESAT program for the sake of the program continuity itself in the future is tremendous.

The breeders and STIPER do have a high level of importance too in this program. Thanks to the PESAT program, the breeders are facilitated with useful education and knowledge regarding animal husbandry that can be applied in their own hometowns as their internship is over. With this knowledge, a change is expected to happen in their farming customs thus it will affect their farm output in a good manner. STIPER also has a high level of importance in this program. Due to its newborn-status academy so it still has a lot of lack of facilities here and there, particularly a laboratory facility, therefore this program does a big favor in educating 
Table 1. The evaluation of the stakeholders level of importance

\begin{tabular}{lcccccc}
\hline Stakeholders & K1 & K2 & K3 & K4 & K5 & Scores \\
\hline PT KPC & 5 & 5 & 5 & 5 & 5 & 25 \\
$\begin{array}{l}\text { The local government } \\
\text { of East Kutai }\end{array}$ & 3 & 4 & 3 & 3 & 3 & 16 \\
$\begin{array}{l}\text { STIPER of East Kutai } \\
\text { Breeders }\end{array}$ & 3 & 5 & 3 & 5 & 5 & 21 \\
\hline
\end{tabular}

Note: K1= the involvement of the stakeholders in succeeding the PESAT program; $\mathrm{K} 2=$ the compatibility between the stakeholders' work objectives / programs with the PESAT program; $\mathrm{K} 3=$ the contribution of each stakeholder related to the program; $K 4=$ the advantages gained by the stakeholders out of the PESAT program; K5= the importance of the stakeholders in the continued program.

the students. The STIPER education board notices that it takes a huge sum of money to build a farming laboratory, especially a qualified one as the one that PT KPC made in its PESAT program. Nonetheless, this limitation problem was fixed thanks to the program and the agreement between the company and the academy concerning the PESAT cattle shed facility and the other supporting facilities to be transformed into field laboratories.

The local government of East Kutai also has a quiet high level of importance, but it is not as high as the breeders and STIPER academy. The local government - in which this case is the Regional Farm Board - owns a program that matches the PESAT program; that is a breeder groups training. The PESAT program allows the board to sign up and send their trainees to join the internship program run by PESAT. Not to mention, PESAT also supports the local program of increasing the cattle population in East Kutai to be a program promoting the national meat self-supply.

The next step of this research is to create an evaluation of the stakeholders influence in the PESAT program. Among the entire stakeholders above, the one with a high level of importance does not mean it has a high level of influence as well. The evaluation of the stakeholders influence in the PESAT program is described in the Table 2.

The stakeholder which possesses strong level of influence is merely PT KPC as the owner and manager of the PESAT program, its score is 25 points, whereas the other stakeholders such as local breeders, STIPER of east Kutai, and The East Kutai Government still have a weak level of influence in the program (Table 2). Their influence score are 7, 9, and 13 points. It is no wonder actually due to the operation of this PESAT program has been running for barely three years and the internship program for the breeders has only been done in three steps, hence the company still holds the biggest influence in the development of PESAT predominantly, nevertheless, it is expected to have a great affect for the success of the program. After the evaluation of the level of importance and influence was complete, then the research embarked on the mapping of both levels into a matrix of stakeholder analysis. This matrix is used to map the importance and influence of the stakeholders (Reed et al., 2009). It is assembled of four quadrants portraying
Table 2. The evaluation of the stakeholders level of influence

\begin{tabular}{lcccccc}
\hline Stakeholders & P1 & P2 & P3 & P4 & P5 & Scores \\
\hline PT KPC & 5 & 5 & 5 & 5 & 5 & 25 \\
$\begin{array}{l}\text { The local government } \\
\text { of East Kutai }\end{array}$ & 3 & 1 & 1 & 4 & 4 & 13 \\
$\begin{array}{l}\text { STIPER of East Kutai } \\
\text { Breeders }\end{array}$ & 1 & 2 & 1 & 2 & 3 & 9 \\
\hline
\end{tabular}

Note: $\mathrm{P} 1=$ the role of the power to the PESAT program; $\mathrm{P} 2=$ the level $/$ degree of the foundations in decision making; $\mathrm{P} 3=$ financial support; $\mathrm{P} 4=$ human resources support; $\mathrm{P} 5=$ relations with the other stakeholders.

the each stakeholder positions in the development of PESAT program. This step was conducted in order to determine the strategy of the stakeholders involvement. The distribution positions of the stakeholders according to their level of importance and influence in the PESAT program can be seen on the Figure 2 .

As depicted above, the key player of the overall PESAT program is PT KPC. PT KPC is the most active stakeholder in the PESAT program, completely. It happens since PT KPC has a high level of importance and influence in the program. As already been explained before, this PESAT program is one of the commitment programs of the company regarding its social work (Company Social Responsibility, CSR). By operating well-qualified CSR programs, the company will earn a better reputation in the eye of the other stakeholders. CSR agenda is an obligation assigned to every company by government which also requires an innovation relevant to the needs of the local society that must be able to benefit those people. The PESAT program this far possesses the potentials towards the goal, and in consequence, PT KPC as a company capable of fulfilling those compulsory tasks has high-leveled importance so that the PESAT program can operate optimally. Moreover, there are various numbers of advantages received by the company from PESAT, whether concrete or abstract advantages. With lots of these advantages, then the involvement of PT KPC in succeeding the program is absolutely necessary. As well as the company's importance, the influence of PT KPC in the PESAT program is high too. The good performance of the PESAT program depends on how serious PT KPC take cares of the program in the future. Besides, this company also pays a great scale of contribution for the program, such as giving the financial support, the human resources support, and the essential facilities. This is similar with Jensen (2007) who said that the company social programs must be earnest and pure aims for the public benefit without any other motive.

From the last image, it is obvious that the stakeholders in the subject quadrant are consisted of the local government of East Kutai, STIPER academy, and the breeders. The three stakeholders indeed own a high level of importance, yet a small portion of influence in controlling or changing any events or circumstances. The local government is important for the PESAT program concerning the compatibility of the work programs. 


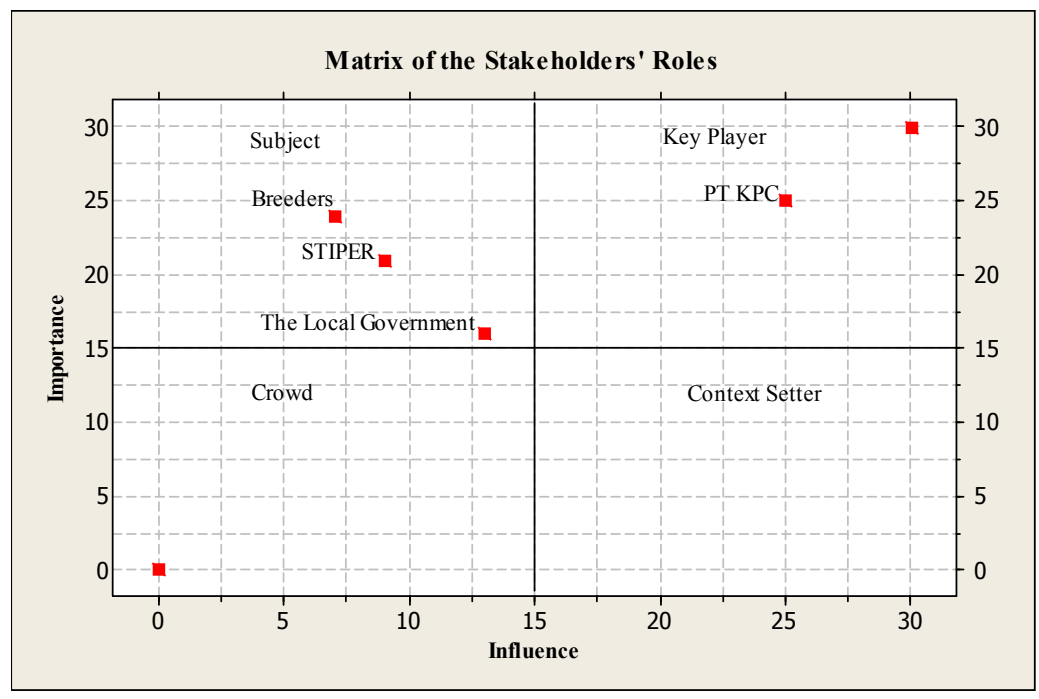

Figure 2. Matrix of the stakeholders roles in the PESAT program

PESAT program, which includes training and breeding for Balinese cattle, is really crucial for educating the breeder groups and escalating the cattle population. Both of the STIPER academy and the breeders have their own important parts in knowledge advancing. PESAT gives a helpful hand to STIPER by letting the academy to use PESAT facilities as their field laboratory, while the breeders get more educative information about animal husbandry through the internship program offered by PESAT. Unlike the role of the importance, the influence of these three stakeholders is quite minor. The three have no power in managing the PESAT program, and it is due to the mighty influence and contributions of PT $\mathrm{KPC}$ in running and managing the program. Although, overall, the analysis result shows a small amount of influence of those three stakeholders, but the local government of East Kutai possesses a pretty strong influence in its relation to human resources support; as training consultants and instructors. Among the stakeholders trio with low influence, the breeders are the stakeholder that has the lowest one. In some evaluation variables, all of them display criterions ranked as very low and low, so a more active cooperation with the other stakeholders is vital. This sort of cooperation will need an involvement within the existing stakeholders; whether between one stakeholder with another stakeholder or more in one same quadrant, or outside of a certain quadrant. It is necessary to create such cooperation in order to benefit the entire stakeholders. The company needs to involve the other stakeholders in upgrading the program and its continuity. The local government of East Kutai and STIPER can be involved in managing the selection process of new interns and breeders, who are the main objects in the internship program, specifically in technical-decision making, for example: the training duration, the training subjects, and mentoring. This condition is slightly different from the results suggested by Spitzeck \& Hansen (2010) who found that stakeholders in the research has been given voice by the company on matters of managerial and operational strategies of the company, although in the end the involvement of stakeholders is low.

From the three stakeholders who are in quadrant subject, the local government and STIPER of East Kutai are still possible to increase their influence level in this program. The East Kutai Government is able to have a higher influence in this program, by increasing the level of the variable in the decision-making and financial support to the program, although it is done as needed. STIPER of East Kutai also can increase its influence on the program by optimizing the variable level of decision-making, human resource support, and strengthen relationships with other stakeholders. The stakeholder theory suggests that the relationship between a company with other stakeholders is a crucial asset that should be well-managed by a manager (Post et al., 2002). Knowing that this PESAT program is one of the CSR programs of PT KPC, which is located in a used-mining area, then the stakeholder approach through this analysis, might be an alternative to evaluate the performance of the company with the other stakeholders. It is like what Jamali (2008) quotes that a stakeholder approach regarding CSR matters offers a practical alternative to evaluate a company's performance on key stakeholders.

The contract between PT KPC and the Local Government East Kutai will end - in 2021. The company estimates the total of 90938 hectares of mining area, only 30.000 hectares were exploited until the end of the contract, so there is still possibility for PT KPC and Government of East Kutai District to continue the contract. If we assume the contract will be ended in 2021, or in other words, PT KPC will not continue the contract, it is necessary to consider the optimization of PESAT management until the end of 2021.

In the previous discussion, it is said that there are several stakeholders who have an interest in this program, including the PT KPC, local breeders who are indeed a priority target since the beginning of the construction of this program, STIPER of East Kutai, and local government. The initial goal of PESAT Program 
made a beef cattle breeding center and a training center of the Balinese cattle, and prepare them to be a business alternative in a post-mine closure in 2021. Based on it, the purpose of this program is geared to the success of breeders in internalizing the training that they get for their business activities in the field. In addition, this program is expected to be an alternative of business training center in East Kutai.

If PESAT program hold one training with six trainees every year, they will be 54 trainees until 2021. If the assuming of the success rate from the farmer training is $90 \%$, they will be 48 breeders who are still continuing efforts Balinese cattle business until the end of 2021. These 48 people are expected to be a pioneer for others to become the successful breeders in their respective regions. They are also expected to be the profile of the successful society who operate in Balinese beef cattle farm, so it can be a motivation for other breeders or people who are interested in the business field of animal husbandry. By these conditions, the original purpose of PESAT to prepare the alternative economy in post mine closure will actually occur actually.

In addition, one of the benefits of the program that can be optimized is the utilization of biogas products. Nowadays, the biogas generated is still limited to pilot the biogas lights and as the fuel in internal gas stove employees, then the product can be empowered to surrounding communities in the future. With better packaged, this product can be commercialized. Breeders who have been trained and continue beef cattle business in the future also can optimize the benefits of biogas produced products from cattle. By investing tool that can convert waste into gas, then the perceived benefits of biogas can be utilized by the community. If the farmer has two cattles that can produce the $0.2-2 \mathrm{~m}^{3}$ of gas per day; to scale the number of households with 2-4 cattle heads can use a tube reactor with a capacity of 2,500-5,000 L to produce biogas to the equivalent of $2 \mathrm{~L}$ of kerosene per day and is able to meet the energy needs of rural households cook with 6 family members. It means that farmers who have two cattles can save money equivalent of $2 \mathrm{~L}$ of kerosene per day or 900 thousand per month, assuming a price per liter of kerosene Rp15,000, so in one year can save household expenditures of Rp10,800,000. The greater the number of cattle population in one place, then the potential of biogas produced was further optimized for their purpose, eg for lighting.

Based on the identification of benefits that conducted, PESAT is as a training center for breeders and a laboratory for STIPER of East Kutai, also according to the position of stakeholders on stakeholder analysis; it is no exaggeration to conclude that the greatest contribution from the program PESAT to society is in terms of science achievement. The stakeholders that feel the benefits of the program are breeders and STIPER of East Kutai. Present until 2021, socialization programs about animal husbandry, particularly cattle needs to be done as part of efforts to prepare for an economic alternative post mine closure. Although this is a difficult work, the program is also expected to change the community perception that the businesses in the livestock sector has less promising, especially compared with the mining sector.
PESAT as the center of Balinese beef cattle farm training can take on that role, because, this program does not just bring the benefit for the breeders who have an opportunity to attend training, but also to breeders who cannot attend the training. Indirectly, the profile of the successful breeders who have been trained is also one way of socialization efforts in the field of animal husbandry. Breeders who have been trained can also be a mentor to others in the group of cattle ranchers. Socialization programs can also be done by working with STIPER of East Kutai. STIPER of East Kutai through community service programs do outreach to the local community about the importance of preparing alternative farm enterprises in the field.

In addition, the cooperation with the Government of East Kutai District has to be increased in order to reach the standard of Bali cattle breeding. Due to this program was instrumental in the addition of local cattle population and meat self-sufficiency that launched by the government, the government of East Kutai District can help to increase the quality of cattle performance in animal health, including vaccination improving the quality of cattle performance with the control routine animal health, including vaccination. Another collaboration can also be done in the case of cattle pregnancy. PESAT can enlist the services of artificial insemination (AI) which will be launched by the East Kutai local government through the Department of Animal Husbandry, so PESAT destination in Balinese cattle breeding is achieved easily.

According to the institutional theory, it can use some of the existing policy to manage this program in future. The first, the Leviathan policy, this policy may involve a third party such as the government to manage the program. The second is privatization policy, this policy is fully handed over to the private sector, in this case, we recognize the company ability to manage the program very well, both in terms of financial, human resources, and etc. The third policy is the management of self-organization that is involving a group or community. Finally, the decision of which the policy that is chosen to manage the program may change over time.

\section{CONCLUSION}

PT KPC as the owner and manager of the PESAT program is still the one and only key player of the program. PT KPC has high importance and influence in the program, while the other stakeholders are merely receiving the advantages out of it (acting as users). The three remaining stakeholders; the local government of East Kutai, STIPER of East Kutai, and the local breeders; have high importance in the program yet low influence, making the three categorized in the subject quadrant.

\section{REFERENCES}

Ackermann, F. \& C. Eden. 2011. Strategic management of stakeholders: theory and practice. Long Range Plann. 44:179196. http://dx.doi.org/10.1016/j.lrp.2010.08.001

Brugha, R. \& V. Zsuzsa. 2000. Stakeholder analysis: a review. Health Policy Plann. 15:239-246. http://dx.doi.org/10.1093/ heapol/15.3.239 
De Lopez, T. T. 2001. Stakeholder management for conservation projects: a case study of Ream National Park, Cambodia. Environ. Manage. 28:47-60. http://dx.doi.org/10.1007/ s002670010206

Fraser, E.D.G., A.J. Dougill, W.E. Mabee, M.S. Reed, \& P. McAlpine. 2006. Bottom up and top down: analysis of participatory processes for sustainability indicator identification as a pathway to community empowerment and sustainable environmental management. J. Environ. Manage. 78:114127. http://dx.doi.org/10.1016/j.jenvman.2005.04.009

Friedman, A. \& S. Miles. 2006. Stakeholders: Theory and Practice. Oxford University Press, Oxford.

Gunawan, A. \& Jakaria. 2011. Genetic and non-genetics effect on birth, weaning, and yearling weight of Bali cattle. Med. Pet. 34:93-98. http://dx.doi.org/10.5398/medpet.2011.34.2.93

Iqbal M. 2007. Analisis peran pemangku kepentingan dan implementasinya dalam pembangunan pertanian. Jurnal Litbang Pertanian. 26:89-99.

Jamali, D. 2008. A stakeholder approach to corporate social responsibility: a fresh perspective into theory and practice. J. Bus. Ethics. 82:213-231. http://dx.doi.org/10.1007/s10551007-9572-4

Jensen, K. K. 2007. Corporate responsibility: the stakeholder paradox reconsidered. Journal of Agricultural and Envi- ronmental Ethics. 20:515-532. http://dx.doi.org/10.1007/ s10806-007-9068-3

Post, E., E. Preston, \& S. Sachs. 2002. Managing the extended enterprise: the new stakeholder view. Calif. Manage. Rev. 45:6-28. http://dx.doi.org/10.2307/41166151

Reed, M.S., A. Graves, N. Dandy, H. Posthumus, K. Hubaek, J. Morris, C. Prell, C. H. Quinn, \& L. C. Stringer. 2009. Who's in and why? a typology of stakeholder analysis methods for natural resource management. J. Environ. Manage. 90:1943-1949. http://dx.doi.org/10.1016/ j.jenvman.2009.01.001

Rietbergen, J. \& D. Narayan. 1998. Participation and Social Assessment, Tools and Techniques. The International Bank for Reconstruction and Development, Washington DC.

Stringer, L. C., C. Prell, M. S. Reed, K. Hubacek, E. D. G. Fraser, \& A. J. Dougill. 2006. Unpacking 'participation' in the adaptive management of socio-ecological systems: a critical review. Ecology and Society 11:39 (online). http://www. ecologyandsociety.org/vol11/iss2/art39/

Spitzeck, H. \& E. G. Hansen. 2010. Stakeholder governance: how stakeholders influence corporate decision making. Corp. Gov. 10:378-391 (online). http://dx.doi.org/10.1108/ 14720701011069623 